\title{
Sustainable development, climate policy and environmental transformation of the Baltic region economies: a comparative analysis
}

\author{
Anatoly Stepanov ${ }^{1}$, Alexander Burnasov ${ }^{1, *}$, Maria Ilyushkina $^{1}$, Yury Kovalev $^{1}$, and Gulnara \\ Nyussupova ${ }^{2}$ \\ ${ }^{1}$ Ural Federal University, Lenina Str., 51, 6200083 Ekaterinburg, Russia \\ ${ }^{2}$ Al-Farabi Kazakh National University, al-Farabi Ave., 71, 050040 Almaty, Kazakhstan
}

\begin{abstract}
The article considers the climate policy of the Baltic region countries. The reasons and factors for reducing $\mathrm{CO} 2$ emissions in the period 1990-2018 are analyzed, the relationship between the processes of decarbonization and the ecological transformation of farms are demonstrated. The EU influence on the climate policy of individual countries is studied. The features of evolution and the modern structure of the RES sector are explored. The assessment of measures to improve energy efficiency of national economies is given. According to the degree of climate policy efforts and the depth of the ecological transformation of national economies, a ranking scheme for the region countries is proposed.
\end{abstract}

\section{Introduction}

According to the definition of the Brundtland Commission, «Sustainable development is the development that meets the needs of the present without compromising the ability of future generations to meet their own needs" [1]. Sustainable development includes a wide range of goals and objectives that can be differentiated into 4 groups: environmental, social, economic, and political. Nowadays, the main global environmental problem is the Earth's climate change. The report of the World Meteorological Organization (WMO) notes that 2019 was the warmest year in the meteorological observation history [2]. Climate change threatens the stability of the socio-economic and political systems of the territories. Without complex political measures aimed at curbing the processes of global climate change, any sustainable development of the regions seems to be impossible. Regional climate policy and the associated ecological transformation of the economy are becoming one of the tools for implementing the concept of sustainable development. Climate policy is understood as "the actions of the actors within the political field influenced by formal and informal institutions that work to resolve the global climate problem" [3, 4]. Climate policy is multi-level. It is implemented at the global, macro-regional, national and local levels. These levels are closely related. The relationship between them is non-linear, but complex. The climate policy goal is to stabilize the concentration of greenhouse gases in the atmosphere at a level that will prevent dangerous anthropological interference with the planet climate system [5,

\footnotetext{
* Corresponding author: asburnasov@urfu.ru
} 
6]. Its central instrument is the decarbonization of the economic structures. Global climate change directly affects the state of the geosystems in the Baltic region. Extremely high summer temperatures in 2018-2019 led to large-scale forest fires and loss of agricultural production in many states of the region. Under the influence of climatic factors, the physical characteristics of the main region-forming structure, the Baltic Sea, change. According to the German Der Spiegel Journal, the average annual temperature of the Baltic Sea water has been steadily increasing over the past 30 years, and acidity and oxygen depletion are increasing as well [7]. In turn, changes in the physical indicators of the sea are reflected directly in its biodiversity: the number of "invasive" organisms grew to 110 species compared to the beginning of the 20th century, the structure and number of biopopulations changed [8]. Rising sea levels threaten to destroy the coastline and infrastructure of coastal cities in the region. At the same time, the countries of the Baltic region (EU and the Russian Federation) occupied the $3^{\text {rd }}$ place in the world in 2018 in terms of greenhouse gas emissions, behind were only China (11.3 billion tons) and the United States ( 5.3 billion tons). The main producers of emissions in the region are Russia (58\% of regional emissions), Germany (25\%), Poland (11\%). The dominant component in the emissions structure is $\mathrm{CO} 2$. Burning hydrocarbon energy sources generates $88.1 \%$ of its emissions in developed countries. Therefore, the rejection of the use of hydrocarbons as energy carriers and the transition to a "clean" economy based on renewable sources (RES) is considered as a key factor in decarbonization of the economy of these countries. Thus, it becomes the main method of struggle to curb global climate change. At the same time, the policy of the Baltic region states "ecological transformation" has featured modernization and geopolitical projects. Moreover, in the Baltic region there is a significant spatial differentiation between its members in the level of the achieved ecological transformation of societies, public perception of the global climate problem, as well as in the goals and objectives of the national climate policy. The high dependence of individual national economies on the hydrocarbon resources at their disposal is becoming one of the main factors of the "weak" national climate policy and a serious barrier to environmental transformation.

The study of climate policy and the processes of national systems ecological transformation, both in our country and abroad, has been conducted recently. Among the researchers, it is necessary to highlight the works of N.N. Moiseev (2001), V.I. DanilovDanilyan (2015), A.A. Averchenkov (2009), A.O. Kakorin (2013), Y. A. Rusakova (2016) and others. Foreign researchers O. Edenhofer (2017), G. Simonis (2017) (Edenhofer, 2017. Simonis, 2017) made a significant contribution to the study of climate policy and environmental transformation. The issues of the international climate policy evolution have been deeply studied. Research on the climate policy comparative analysis and transformation processes in various countries is less represented (G. Simonis, 2017). Especially there is a lack of research in comparing climate policy in macroregions that combine different historical paths of development, culture, economic and social structure of the state. One of these regions is the Baltic region. A huge contribution to its study was made by the Russian social geographers Fedorov G.M., Zverev Y.M., Korneevets V.S. Our study covers the geographical aspects of the region states climate policy. The climate policy pursued by the countries of the region and their achievements in the field of ecological society modernization are unique. In a short period of time, the countries of the region have managed to achieve significant results in decarbonizing industries and developing renewable energy. Some countries in the region are generally recognized as the world leaders in the field of climate policy while others are deficient in its implementation. The purpose of the article is to consider the peculiarities of climate policy and decarbonization processes in the countries of the Baltic region in the period of 1990-2020, to analyze the reasons and factors that influenced the climate policy in the states, to determine the degree 
of ecological transformation of economic structures. In conclusion, the author's grading scheme for the Baltic region countries according to the current climate policy and environmental transformation level is proposed.

\section{Materials and Methods}

The theoretical basis of this study is formed by the "path dependence" concept, which means the dependence of the country's political and socio-economic development trends on the previous stages of development (D. North, P. David, G, Grabher, A. Azwan). Also, the basis was the network management of multilevel political systems theory (J. Richardson, A. Jordan, D. Marsh., J. Pierre and others) [9]. From the first concepts point of view, climate policy can be viewed as a project of socio-economic modernization. The ecological transformation of the economy is seen as the transition of the society to a new level of technological development (Yanike M, Hayer M.) [10]. However, like any "modernization project", environmental modernization encounters tangible obstacles on its way. Various types of "blockades" have their own national peculiarities and are closely related to the historical features of the particular state development. There are significant differences between the countries of the Baltic region in the speed of implementation of the goals and objectives of the climate policy, as well as the pace of environmental modernization of national economies. Some countries of the region are acting as world leaders in environmental transformation whereas others play the role of outsiders because of the peculiarities of their development and the structural features of the economy. At the same time, the hydrocarbon dependence of the economy is becoming a constraining factor in its transformation. The higher it is, the stronger the inertial processes of socio-economic development are. This is reflected not only in the rate of implementation of environmental technologies, but also in the attitude of the society and political elites of the countries to the global climate problem. Hydrocarbon anti-modernism threatens the positive dynamics of the evolution of the national economic systems, their transition to a new level of development, which leads to a lock in and the loss of the ability to renew their structures [11].

The theory of multilevel governance emphasizes the increasing importance of various actors interacting at different levels in the development and implementation of state policy. State actors of various levels (supranational, national, regional), as well as non-state actors (civil society, enterprises) have a huge impact on the formation of the state's climate policy. Especially the EU member states are under the pressure in political decision-making from various interest groups at various levels. Representatives of network governance concept speak of the erosion of the state both "from above" (supranational bodies, international organizations) and "from below" (national and regional political networks, civil society, business) [12]. These trends are reflected directly in the domestic and foreign policies of the Baltic region countries. The climate policy of the EU member state is influenced by both directives and instructions of the EU Commission, constant monitoring by supranational agencies and international organizations. However, the initiatives of local structures, often expressed in a protest form, are a powerful factor influencing the state climate policy (for example, the public movement "Fridays for the Future"). In addition, the EU creates conditions for cooperation between states and stimulates the development of advanced projects. Also, with the help of financial levers, the central bodies of the EU can have a huge impact on changing the vector of climate policy of national states [13].

The methodological basis of this article is formed by the structural-analytical and comparative approach. The analysis of the positions of the countries reflected in national climate strategies and national statistics allows us to determine the character, directions and achievements of the climate policy of these countries. In addition, it helps to assess the 
influence of certain factors (external and internal) on the processes of environmental transformation of national structures. The main environmental transformation indicators were indicators of the CO2 emissions dynamics in 1990-2018 period, the rate of introduction of renewable energy sources, both in the economy as a whole, and in the transport sector separately, as well as the assessment of measures to improve the energy efficiency of national economies. The main sources of this publication were based on the EU data, Russian and World Bank static services. Also the scientific works of foreign and domestic specialists were studied.

\section{Results and Discussion}

The countries of the Baltic region do not represent an integral, unified legal region carrying out a coordinated climate policy. Eight countries out of nine in the region are EU members. In accordance with the Lisbon Treaty (Article 10, Chapter 1), the EU countries act as a single political factor in the international arena in the field of environmental protection. Chapter 1, Article 10 of this treaty refers to the common efforts of the EU countries to "promote the development of international measures of maintaining and improving the quality of the environment and sustainable management of global natural resources in order to ensure sustainable development" [14]. Indeed, the unified environmental policy of the EU, institutionalized in the community in the early 1970 s, had a tremendous impact on the formation and development of international sustainable development policy, as well as on the unification of environmental standards of the organization's member states. Since the late 1980s the EU is acting as the world leader in creating a "strong" global climate regime. Two years before the famous conference in Rio de Jainero (1992), the EU Council of Ministers for Energy and Environment in October 1990 took a decision to stabilize CO2 emissions by 2000 at the 1990 level [15]. The EU was one of the initiators of the Kyoto Protocol creation. Thanks to the efforts of the EU, the world community has set tremendous plans on controlling global climate change, reflected in the Paris agreement.

In the EU, dozens of regulations, directives in the field of climate protection and environmental transformation of the economy were enacted. In 2008, the EU adopted a climate and energy package 2020, which provides for a reduction in $\mathrm{CO} 2$ emissions, an increase in the share of renewable energy sources in the energy consumption structure and an increase in energy efficiency until 2020 (project 20-20-20). In 2014, a similar package was adopted until 2030 (40-27-27). However, the ambitious goals of the Paris Treaty required a revision of this plan. In 2018, the EU Commission adopted a legal line (2018/2001) with the updated goal of increasing the share of renewable energy sources by 2030 up to $32 \%$. Finally, in 2020, the EU Commission presented an economic development project of the European Union until 2050 called the European Green Plan. A comprehensive ecological transformation of the European Union economy by 2050 and the transformation of the EU into the first climate-neutral region in the world are discussed in the project [16]. At the same time, national plans for climate and energy policy until 2030 were directed to the EU Commission.

Russia, as a country with a strong reliance on hydrocarbon economy, adhered to (and adheres to) a "weak" climate policy. Its interests coincided with the goals of the OPEC countries (COP 1 in 1995), and later with the JASCANNZ countries (Japan, USA, Switzerland, Canada, Australia, Norway and New Zealand), with which the Russian Federation forms the so-called. "Umbrella group". The countries of this group are characterized by a skeptical position regarding the causes of global warming, the effectiveness of certain instruments in the fight against it.

Russia is a participant of the 1992 UN Convention, which committed itself to initiating national climate stabilization measures. The economic crisis in the country in the 1990s. 
predetermined the achievement of Russia's climatic goals in 2000. In 2004, the country ratified the Kyoto Protocol, and took an active position at all conferences of the parties since 1995. In 2008, the government of the Russian Federation approved the country's climate doctrine. In 2015, Russia signed the Paris Agreement, but only in October 2019 it was officially approved [5]. Since the summer of 2018, the Russian government has been preparing a national action program (national strategy) to combat global climate change. In the decree of the President of the Russian Federation on national development goals for the period up to 2030 (No. 474 from July 21, 2020), the goal is to double the reduction of emissions of environmentally hazardous substances [17]. However, there is no specification in the document. Whether greenhouse gases are included in the category of "environmentally hazardous emissions" or not is still under consideration. The countries of the EU of the Baltic region play an important role in the formation and implementation of climate policy goals. However, along with the directives and decrees of the EU Commission, setting the general directions of political development, the development of specific goals, objectives and instruments of climate policy remains the prerogative of the national states. Here we see significant differences in the pursued climate policy, in its goals and objectives, as well as in the speed of environmental modernization between the countries of the Baltic region. Let us first consider the dynamics of greenhouse gas emissions in the countries of the region. The countries of the EU Baltic region have a relatively high share of the total carbon emissions of the member countries of the organization. Eight countries of the Baltic region (excluding Russia) accounted for $36 \%$ of all EU emissions. At the same time, the share of two states of the region - Germany and Poland - exceeded $86 \%$ in this group. The smallest volume of emissions in 2018 was a characteristic of the small countries of the region - Latvia, Lithuania, Estonia (Table 1). Russia's emissions exceeded by 490 million tons of all countries in the region. According to this indicator, the Russian Federation is one of the five largest countries in the world. Also, in terms of per capita indicators, Russia (12.1 tons) is inferior to only one state in the region - Estonia (18.6 tons a person) [18].

In 1992, all countries in the region joined the United Nations Framework Convention on Climate Change and made specific commitments. Some of the countries of the region included in the list of Appendix II (Denmark, Sweden, Germany and Finland) have taken on specific targets for reducing $\mathrm{CO} 2$ emissions. Another part of the states of the region, mentioned in the Appendix of Convention I and calling themselves the so-called "Countries with transition economies", according to the article 2.6 of the convention, were entitled to more flexible policies regarding emission reduction commitments aimed at supporting economic growth [9]. Indeed, in the period 1990-2018, in all countries of the region, the processes of reducing greenhouse gas emissions were observed. However, the differences in the levels of reductions were significant - in the countries of the application of Convention I (countries with transition economies), emissions fell by $40 \%$. At the same time, the developed countries of the region (countries of Appendix II) reduced their emissions by $26.5 \%$. Among the countries of the region, a strong decrease in emissions was observed in Latvia (62\%), Lithuania (60\%), Denmark (40\%), Estonia (37\%). The average level was demonstrated by Germany (27\%), RF (26\%), Sweden (24\%). The smallest Finland (15\%) and Poland (10\%) [calculated by the authors till:13]. Also, in all countries, carbon emissions per capita decreased significantly, with the exception of Poland (Table 1). 
Table 1. Dynamics of $\mathrm{CO}_{2}$ emissions in the countries of the Baltic region within the period 19902018

\begin{tabular}{|c|c|c|c|c|}
\hline \multirow{2}{*}{ Country } & \multicolumn{2}{|c|}{$\mathbf{C O}_{\text {e emissions, } \text { million tons }}$} & \multicolumn{2}{c|}{ CO $_{\text {emissions, tons per capita }}$} \\
\cline { 2 - 5 } & $\mathbf{1 9 9 0}$ & $\mathbf{2 0 1 8}$ & $\mathbf{1 9 9 0}$ & $\mathbf{2 0 1 8}$ \\
\hline Denmark & 53,6 & 33,1 & 10,4 & 5,7 \\
\hline Germany & 1018 & 752 & 12,8 & 9,1 \\
\hline Latvia & 20,1 & 7,8 & 7,5 & 4,0 \\
\hline Lithuania & 35,3 & 14,4 & 9,5 & 5,0 \\
\hline Poland & 371 & 334 & 9,7 & 8,7 \\
\hline Finland & 57,2 & 48,7 & 11,4 & 8,8 \\
\hline Sweden & 58,1 & 44,5 & 6,7 & 4,4 \\
\hline Estonia & 38,4 & 24,3 & 24,5 & 18,6 \\
\hline Russia & 2355 & 1748 & 15,9 & 12,1 \\
\hline
\end{tabular}

Source: compiled by the authors according to [18].

If we analyze the data on the reduction of $\mathrm{CO} 2$ emissions for the time intervals of this period (1990-2000, 2000-2010, 2010-2020), then the following patterns can be distinguished. In the post-socialist countries of the region, the peak of the drop in emissions occurred in the early 1990s. In the industrialized countries of the region it happened at the beginning of 2000. Thus, in Estonia, Latvia, Lithuania, a drastic reduction in emissions was observed in the period 1990-1995. (double drop). On the contrary, in Sweden and Denmark at this time these indicators reached their historical high levels. Emissions peak in Finland $\mathrm{CO} 2$ was in 2004. Emissions from the developed countries of the region in 2000 exceeded those in 1990. Noticeable reductions in emissions began to be noted only in the years after the millennium.

This fact indicates that, firstly, the declared goals in the UN Framework Convention on Climate Change on average for the countries of the region included in the list of Appendix II were not achieved. Secondly, the main factor in reducing emissions in countries with transition economies was the decline in industrial production and the decline in the living standards of the population that followed the collapse of the USSR. The decline in industrial production and energy reforms affected the share of these sectors in the structure of national CO2 emissions. In Estonia, Latvia, Lithuania, Russia and Poland, carbon emissions from the energy sector and industry have more than halved. At the same time, in Denmark, Sweden, Finland and Germany - only by $25 \%$. At the same time, the small postsocialist countries of the Baltic showed the largest reduction. In Latvia, emissions from the energy sector decreased by $80 \%$, Lithuania - 88\%, Estonia - 42\% [18]. The CO2 emissions of the industrial sector of these countries decreased by 65.6 and $81 \%$, respectively, which is two or more times higher than the indicators of the developed countries of the region. There is also a noticeable direct correlation between these $\mathrm{CO} 2$ emissions from the energy sector and the dynamics of per capita electricity consumption in the Baltic region countries. In all countries with a drastic drop in emissions in the 1990s. processes of significant reduction of electricity consumption were observed in parallel. In Latvia, per capita energy consumption fell by $42 \%$, Lithuania - 37\%, Estonia - 27\%, Russia - 24\% and Poland - 6.5\% [19]. In all other countries in the region, individual consumption increased in the 1990s. Consideration of the dynamics data for different moments of this period, sectoral features allow us to conclude that the main factor in reducing $\mathrm{CO} 2$ emissions in the countries of the former socialistic camp became the economic crisis and, as a consequence, a reduction in industrial production and electricity consumption. The share of manufacturing in the structure of GDP of these countries decreased significantly [20].

The decrease in carbon emissions in the countries of the Baltic region was not only a consequence of the progressive de-industrialization, but also kept abreast of the times with 
the processes of environmental transformation of their economies. The emergence and rapid development of the renewable energy sector (RES) has become a characteristic common feature of almost all countries in the region.

As it has been noted above, the use of fossil fuels as energy sources is the main reason for the increase in the concentration of $\mathrm{CO} 2$ in the atmosphere of the planet. Therefore, since the beginning of the 1990s in most countries in the region, national programs on the development of a complex of alternative energy have been adopted. In addition, the EU, with the help of legislative acts and legal lines, has had a huge positive impact on the development of this area. Since 2009, there has been a legal line on renewable energy sources $(2009 / 28$ / EG), the goal of which is to increase the share of renewable energy sources in EU energy consumption up to $20 \%$. At the same time, all countries in the region adopted national laws which stimulate the development of these energy sources.

The countries of the Baltic region are both European and partly world leaders in the development of this industry. In 2018, the share of RES in the final consumption of energy resources was $29.5 \%$ (together with the RF). This is almost 1.5 times higher than the EU average indicators (18\%) [21]. Meanwhile, Sweden, Finland, Denmark, Latvia and Estonia were in the top five EU countries in 2018 in terms of the development of the renewable energy sector. The lagging countries in this area are Germany, Poland and the Russian Federation. According to the World Bank and the European Bureau of Statistics, the share of renewable energy sources in the structure of energy consumption in these countries is lower than the European indicators. The huge dependence of the Russian economy on hydrocarbons impedes the development of this sector. Thus, according to the World Bank, the share of renewable energy sources in energy consumption decreased in the period 19902015 in the Russian Federation by $0.4 \%$ (Fig.1). Meanwhile, Rosstat points to the growing role of renewable energy sources in energy production in the country. The share of energy resources produced using renewable energy sources was $17.6 \%$ in 2019 in the total energy resources of the country, accordingly [6].

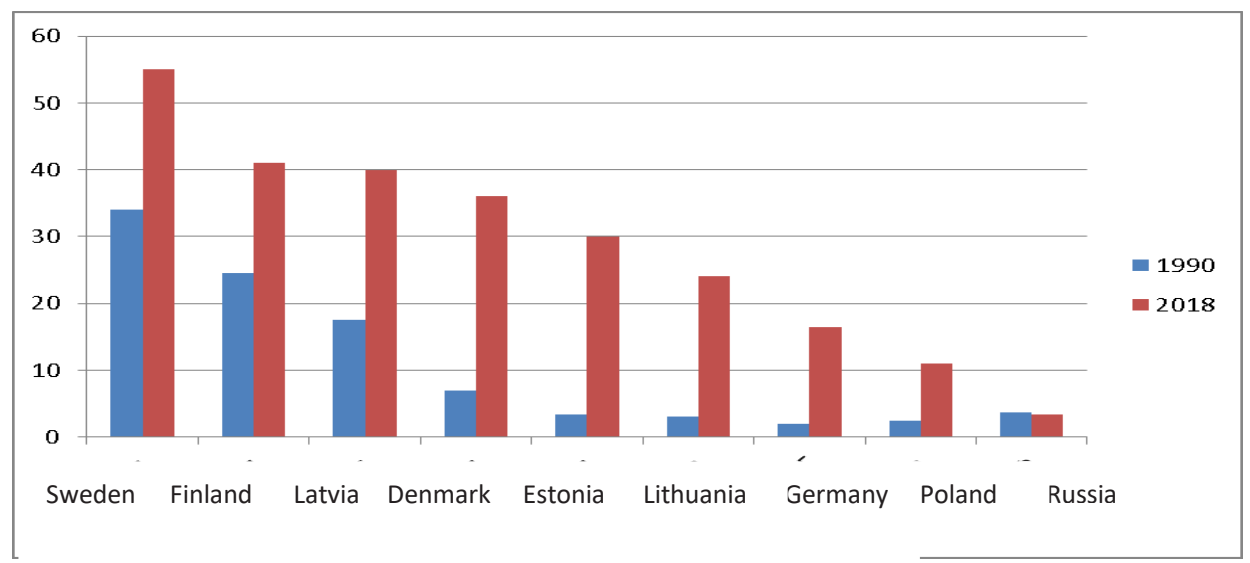

Fig. 1. The share of RES in the total structure of energy consumption in the Baltic region countries (1990 and 2018).

In the period of 1990-2018, the share of RES in the consumption of all energy resources was steadily increasing. Especially in the two post-Soviet Baltic States, there has been a sharp leap in the development of this sector. If the average share of RES in the structure of energy consumption increased by 2.7 times, in Lithuania it increased by 8 times, in Estonia by 9 , respectively. National strategies became the important factor of RES development in these countries, aimed not only at improving the countries ' carbon balance and achieving climate goals, but also at increasing the independence of the energy sector and reducing its 
dependence on import. Especially reducing dependence on supplies from Russia is a huge priority in these countries. This is due to fundamental political disagreements between them and an immense difference in the perception of international political processes. For the political elite of the Baltic States, the so-called "freedom" from the Russian energy sources has no economic justification, but has purely ideological character. Therefore, the environmental transformation must be perceived not only as an instrument of climate policy, but also as part of a large-scale geopolitical project. The worst results of RES implementation were observed in Poland and Russia. In Poland, the main obstacles to environmental modernization include the dominant discourse of political and economic conservatism and public skepticism about climate policy. Green economy, in general, is considered by the ruling community of Poland as a "leftist" project aimed at the destruction of traditional social and economic structure. The large dependence of the country's economy on the coal industry (about $90 \%$ of energy consumption, 80000 employed people in the industry), the combination of political and economic interests of the national elite prevents the renewal of economic structures and threatens to turn Poland into a backward, peripheral region of the EU (despite the rainbow indicators of economic growth based on giant financial subsidies from the EU). In Russia, the economy's hydrocarbon dependence is even higher. The oil, gas, and coal sectors generated $20 \%$ of GDP, $40 \%$ of the country's budget, and $60 \%$ of its exports in 2019 . Despite the governors understanding of this fact as a threat to national security, the development of alternative, eco-friendly energy has not been properly considered. For example, the text of the national energy strategy of Russia indicates the goal of increasing the share of RES to $4.5 \%$ by 2020 . An important part of the state's climate policy is to promote the development of certain types of RES. Structural analysis of RES in the Baltic States shows significant differences between them in the dominance of various types of energy sources. More than $70 \%$ of renewable energy is generated from wood and agricultural waste in Finland, Poland and Latvia. Fuel biomaterials account for up to $60 \%$ of the RES structure In Estonia. These types of RES are more environmentally friendly than fossil fuels, but they are not neutral in $\mathrm{CO} 2$ emissions. In fact, solar and wind energy belong to the "cleanest" types of renewable energy. Wind energy dominates (77\% and 60\% of RES) in Denmark and Lithuania whereas in Russia the solar energy is used. More than $50 \%$ of RES is accounted for hydropower in Sweden.

The Baltic Sea itself is a giant energy reservoir. Entire wind energy parks have been created in coastal regions and water areas. Nowadays, there are 4 offshore parks and 7 are under the construction in Germany, 9 are in Denmark and 4 - in Sweden, respectively. Since 2018, the «Ushakovsky» wind Park has been operating in the Kaliningrad region with a total capacity of 5.1 MW. However, traditional hydrocarbon energy sources still dominate in the countries of this region. For instance, the share of shale gas in energy production reaches $85 \%$ in Estonia; coal creates about $90 \%$ of energy in Poland. The third most important indicator of environmental transformation in the region is the energy efficiency indicator of the economy. It is understood as rational efficient use of energy resources in order to reduce their costs in reproduction economic cycles. In international climate policy, improving the energy efficiency of farms is one of the most important tools for countering global warming. Improving the energy efficiency of the society is associated with the optimization of all economic processes, as well as with the widespread introduction of new energy-saving technologies in all spheres of the society. EU Directive 2012/27 / EU sets the goals and policy directions for improving the organization's energy efficiency. Russia has adopted a number of legislative acts aimed at improving the energy efficiency of the economy. Indicator analysis of economies energy intensity (costs of units of cu per $1000 \$$ US dollars of GDP) in the period 1995-2015 shows a decrease in the energy intensity of national households in the region. At the same time, if the indicator of energy intensity is decreased by $23.8 \%$ (from 166.4 to $120.9 \mathrm{~kg}$.f.e. / thousand USD. GDP), then in the 
countries of the Baltic region would decrease by $47.6 \%$ (197 kg.t.) .y. up to $103.4 \mathrm{~kg}$. t.u.). In 1995 this indicator in the region was higher than the global average. In 2015 it was even lower. Thereby, the growth of energy efficiency in the Baltic States was higher than the global average. At the same time, in the post-socialist Baltic countries, there was a noticeably more significant reduction in energy expenditure per thousand dollars of GDP than in other countries of the region. So, energy intensity decreased by $42 \%$ (from $321 \mathrm{~kg}$ to $187 \mathrm{~kg}$ ) in the Russian Federation, in Estonia by 53\%, in Latvia-56\%, in Poland $57 \%$, and in Lithuania-65\%. This indicator fell by $40 \%$ in Denmark and Sweden, and in Finland by $27 \%$. In 2015 the most energy-intensive economy in the region, despite significant improvements, was Russia (187 kg. t.), Estonia (134 kg.t.), Finland (131 kg. t.t.), Denmark (53 kg.u. t.), Germany (74.5), and Lithuania (79) were characterized by low energy costs. In all countries of the region, national strategies for improving energy efficiency in the period up to 2030 were adopted in 2019-2020. For example, Russia's national energy strategy has pointed out the goal to increase energy efficiency by $50 \%$, in Poland by $23 \%$, in Sweden by $50 \%$, and in Germany by $30 \%$.

\section{Conclusion}

The analysis of the results of environmental sustainability policies and environmental transformation processes in the Baltic States allows us to draw the following conclusions. Firstly, in all states of the region since the beginning of the 1990s there have been processes of reducing greenhouse gas emissions. In the republics of the former USSR, the main reason for their decline was the economic crisis and the resulting decline in industrial production and energy consumption. Thereby, the processes of decarbonization were unmanageable in comparison with other countries. In Denmark, Sweden, Finland, and Germany the reduction of greenhouse gas emissions was not so large-scale. Along with the processes of their economic deindustrialization, an important factor in reducing emissions was the ongoing policy to counter climate change and environmental modernization of the economy. Secondly, since the 1990s, the renewable energy sector has been developing rapidly in all countries of the region. RES generate up to $40 \%$ of the energy consumed in the Scandinavian countries of the Baltic region. Sweden plans to completely abandon hydrocarbon energy carriers by 2040 [14]; Denmark, Estonia, Latvia, Finland, Lithuania will have brought their level to $50 \%$ by 2030 . [22; $23 ; 24 ; 11 ; 25]$, Germany - up to $30 \%$ [26]. Russia and Poland are characterized as countries with low development of the renewable energy sector. One of the limiting factors is the huge dependence of these countries on available hydrocarbon resources. Thirdly, in all countries of the region, measures to improve the energy efficiency of economic structures were introduced, and energy costs in the formation of GDP were significantly reduced. However, just as in greenhouse gas emissions, the expansions of the tertiary sector and deindustrialization have had a primary impact on improving these indicators in many countries. Fourthly, a comparative analysis of indicators makes it possible to distinguish separate groupings of countries in the Baltic region by the level of implemented climate policy, as well as by the depth and scale of environmental transformation. Sweden and Denmark form the group of countries with the strongest domestic and foreign climate policies (group 1). Organic reduction of $\mathrm{CO} 2$ emissions was observed in these countries, and the processes of environmental transformations were the priorities of economic development in these countries. By 2050, they plan to create a climate-neutral economy. These countries can also be considered as the world leaders on the international arena. The group with the average and high indicators in the region includes Germany, Finland, Estonia, Latvia, and Lithuania. Although these countries are ranked among the leading states in the region for some indicators, they lag behind the countries of the first group in terms of climate policy 
goals and international efforts (with the exception of Germany). In 2017, Latvia and Lithuania financed the climate Fund at the level of 0.05 and 0.52 cents, respectively, per capita [27]. Poland and Russia belong to a group of countries in the region with "weak" climate policies and little success in environmental transformations. Poland is called a "climate brake" within the EU [28]. Many EU directives are blocked on the initial stages by the countries' governments. However, the EU's influence on the country's policy has a generally positive effect. Due to various EU mechanisms, it is still possible to stimulate environmental transformations in the country. Russia's internal climate policy is characterized, in comparison with other countries in the region, by excessive "restraint" in carrying out environmental transformations. One of the acute problems in Russia is the dependence of economic and social life on the extraction and export of fuel resources. Further emphasis in economic development on "dirty" technologies and "final" resources (coal, oil and gas) threatens the country with technological lag from advanced countries, as well as economic and social regression. Equally important is the drastic reduction of the country's share in global CO2 emissions. Russia is already feeling the negative effects of climate change. Droughts, fires, and floods cause huge financial damage to the national and regional economies and lead to social and political destabilization of local structures. It is expected that these phenomena will be only increasing every year in the country [29].

\section{References}

1. Development and international economic cooperation: environmental problems, https://www.un.org/

2. WMO chief: heat waves and floods that used to happen once a century are becoming the norm, https://news.un.org/

3. G. Simonis, Handbuch Globale Klimapolitik, 558 (2017)

4. Executive Summary Poland's National Energy and Climate Plan 2021-2030, 9 (2020)

5. On Russia's participation in the Paris Climate Agreement (2019), http://government.ru/

6. Federal State statistic service (2020), https://www.gks.ru/

7. Klimawandel: Nord- und Ostsee sind deutlich wärmer geworden, https://www.spiegel.de/

8. A. Krost, Aquakultur und Klimawandel in der Ostsee, 36 (2014)

9. A. Auzan, "Rut effect", The problem of dependence on the direction of the previous development: the evolution of hypotheses, https://cyberleninka.ru/

10. M. Jänike, Megatrend Umweltinnovationen, Zur ökologischen Modernisierung von Wirtschaft und Staat. Münschen, 218 (2012)

11. Finland's Integrated National Energy and Climate Plan, 183 (2019)

12. O. Mikhailova, The state is in search of a new management model, 1, 15 (2013)

13. Polen sieht sich als Sieger des EU-Gipfels, 168 , 5 (2020)

14. Sweden's Integrated National Energy and Climate Plan, 199 (2020)

15. J. Tröltzsch, Die Europäische Union, 302 (2017)

16. Communication on the European Green Deal (2019), https://ec.europa.eu/

17. The President signed Executive Order On National Goals and Strategic Objectives of the Russian Federation, http://en.kremlin.ru/

18. M. Crippa, G. Oreggioni, Fossil CO2 and GHG emissions of all world countries. Luxembourg, 251 (2019) 
19. Electric power consumption (kWh per capita)/ World Bank Data, https://data.worldbank.org/indicator/EG.USE.ELEC.KH.PC?view

20. Industry (including construction), value added (\% of GDP))/ World Bank Data/, https://data.worldbank.org/indicator/NV.IND.TOTL.ZS

21. Anteil von Energie aus erneuerbaren//Eurostat, https://appsso.eurostat.ec.europa.eu/nui/submitViewTableAction.do

22. Denmark's Integrated National Energy and Climate Plan, 184 (2019)

23. Estonia's 2030 National Energy and Climate Plan (NECP 2030), 195 (2019)

24. Latvia's National Energy and Climate Plane 2021-2030, 176 (2020)

25. National Energy and Climate Action Plan of the Republic of Lithuania for 2021-2030, 273 (2020)

26. Integrierte Nationaler Energie- und Klimaplan, 294 (2019)

27. Beitrag zur Internationalen Verpflichtung von 100 Mrd. USD für Klimabezogene Ausganeen//Eurostat, https://ec.europa.eu/eurostat $/$ tgm $/$ table.do?tab $=$ table\&init $=1 \&$ language $=$ de\&pcode $=$ sdg_13_50\&plugin $=1$

28. R. Riedel, Analyse: "Grüner Konservatismus"? Über die polnische Klima- und Energiepolitik, https://www.bpb.de/internationales/europa/polen/285318/analysegruener-konservatismus-ueber-die-polnische-klima-und-energiepolitik

29. The report "On the state and protection of the environment of the Russian Federation in 2018", (2018) 